\title{
THE EPISTEMOLOGICAL GLAUCOMA AND PSEMATICAL PARADOX (AUTOLOGICAL FEATURE OF TRUTH AND HETEROLOGICAL FEATURE OF FALSE)
}

\author{
A.N. Pavlenko \\ Institute of Philosophy of RAS \\ 12/1 Goncharnaya Str., Moscow, 109240, Russia
}

\begin{abstract}
In this paper is considered the main arguments of the deflationary concept of truth: the approaches of A. Tarski, W.V. Quine, H. Putnam and some others. Here are presented two representative examples of the elimination of truth as the value of the proposition: the concept of "languages games" by L. Witgenstein and "constructive empiricism" by B. van Fraassen. It is revealed that the statement "there are no true statements" is self-predictive and leads to absurdity. It is demonstrated that the elimination of "truth" from epistemology will require, with necessity, the elimination of "false" also. It is shown, that when we try to get answer on the question "Can a "false sentence", understood as a "not true" sentence, i.e. $\neg \mathbf{p}$, has the same denotation on which it denotes (not be true)" a paradox arises, which calls "psematic" from the Greek word $\psi \varepsilon \dot{\varepsilon} \mu \alpha \tau \alpha$ (false). The essence of the paradox is that "every false sentence denotes false" denotes every false sentence denoting false, if and only if, "every false sentence denoting false" is not every true sentence denoting the truth. The result is: a) if "every false sentence denoting false" itself is not every true sentence denoting the truth, then, by the definition of "every false sentence denoting false", it is not a sentence denoting false. And vice versa: b) If "every false sentence denoting false" itself is every true sentence denoting the truth, then, consequently, it is "every false sentence denoting false" and it is a sentence denoting false.

In any case, it turns out that the proposition "false sentences denote false", simultaneously have the sign that they designate and do not have it. It was found that "truth" has an autological nature, and "false" has heterological one.
\end{abstract}

Key words: psematical paradox, truth, false, epistemology, ontology, constructive empiricism, lanquage games, G. Frege, A. Tarski, W.V. Quine, H. Putnam

\section{STATEMENT OF PROBLEM}

As it often happens, the discussion of the problem of the existence of truth began simply: a question was asked about what meaning we put in the statement that "the sentence $\boldsymbol{p}$ is true"? How can any proposal be true? The answer was that: the sentence $\boldsymbol{p}$ is true when what is said in the sentence of natural language is really there. Such a correspondent answer goes back to the definition of truth given by Aristotle in Metaphysics [2]:

"To say of what is that it is not, or of what is not that it is, is false, while to say of what is that it is, and of what is not that it is not, is true" (Met.1011b25).

Modern logic, striving for the accuracy of expression, pays attention to what to say that "it is true that $\boldsymbol{p}$ " means simply to say $\boldsymbol{p}$. Alfred Tarski insisted that the natural language is not strict enough, and therefore Aristotle's definition of truth must be 
expressed logically strictly with the help of the equivalence: "the sentence "snow is white' ( $\boldsymbol{p})$ is true if and only if the snow is white". In this case, it turns out that truth is exactly what the equivalence itself is. It turns out that "truth", as a characteristic of the sentence, is redundant, because in this sentence there is an equivalence. But, further, Tarski notes: "In consequence, if we wish to say something about a sentence, for example, that it is true, we must use the name of this sentence, and not the sentence itself" [18. P. 344]. In other words, the left part of the statement mentioned above can be interesting.

W.V. Quine doubted this and noticed that in the first part of the sentence exactly what is contained in the second one is reported. Therefore, it is necessary to disquoted the first part, and we will get a simple tautology. In the name of the proposal — that is, in the quoted expression "snow is white" - there is absolutely nothing that is not in the sentence itself that the snow is white. Therefore, the predicate of truth is nothing more than the procedure of disquoting the first part of the sentence [16. P. 10].

In other words, the truth becomes redundant in our knowledge, turning into a "quoting sentence", then into an "equivalence", then into something else. But since the truth - and to this leads its deflation - becomes redundant, then, consequently, we cannot say about any of our statement that it "is true". And, finally, then comes the most important point - the whole world threatens to turn into our "words game".

In fact, H. Putnam in one of his works "Brains in a Vat" [15] stated that if 1) our signs do not correspond in reality to what we designate, 2) our images do not correspond to anything in reality that we imagine, 3) Finally, our notions do not correspond to anything in reality, which we are trying to grasp conceptually, then, consequently, the whole world that surrounds man is a complete illusion. So, Putnam believed, skepticism is born. To overcome it, he proposed his famous argument, acting as an "honest skeptic", that is, Putnam tried to overcome skepticism not from the outside (from the point of view of another concept), but from within. Here, in my opinion, is his main merit on the issue under discussion.

We have already turned to the analysis of his argument "Brains in a Vat" in another papers $[12 ; 13]$, so we will not dwell on this in details.

We admit that such criticism of the "truth" named above and some other philosophers $[1 ; 3-5 ; 10 ; 14]$ leaves one important question missing: well, "truth" does not exist — it is redundant, it deflates, etc., but the "false" is there or a fallacy — is also our illusion? And if we say "yes", in what sense? This question does not seem trivial any more. In other words, let us try to investigate the nature of falsehood precisely as an object of semantics and epistemology.

\section{GLAUCOMA EPISTEMOLOGICAL}

\subsection{Deflation of "truth" with necessity require deflation of "false"}

The Researchers, who adhere to the concept of deflation of "truth" $[10 ; 16-18]$, in fact, face one unexpected consequence for them, the essence of which follows. If we will normatively understand by "truth" and "false" the allocated values of sentences or 
in other versions - "the conditions for their acceptability", so we cannot disagree with the fact that "truth" and "false" are correlative notions. In their relationship, "truth" is not removable without eliminating "false" and "false" — without eliminating "truth". "False" cannot be eliminated even with the fact that it will be understood as a "negation of the truth".

If this is so, then the assertion of supporters of the deflationary concept of truth, believing that "truth" as the value of our knowledge, is eliminated from epistemology, will necessarily have to admit an elimination of "false", unless they are convinced fallibilists, who believe that our knowledge is only a fallacy.

However, if we eliminate and "false", then, thereby, we open the door for chaos. After all, if there is no truth in knowledge, no false, then this very knowledge of ours has no difference from the singing of birds or the noise emitted by a paddle blow against the water?! Then, everything we do is just footprints on the sand and, consequently, our efforts are vain. But in this case, we cease to be "the eyes of this world".

In this regard, let us allow ourselves one analogy. Imagine that there is a huge Universe, which is a huge organism, and people in it are its "eyes", with which it sees itself. After all, in the human body, the eyes are just a very small part of the whole organism. But in importance they immeasurably surpass many other organs. Using this analogy, one could say that without our, without human, knowledge, the Universe would be "blind"!

Note that the Universe, from the physics-cosmological point of view, will stay the same as it was, but blind. After all, a person deprived of vision, from the physicschemical point of view, does not differ from a person who is sighted.

But then both fallibilism and the deflationary concept of truth are something like "eye glaucoma" in ontology and epistemology. However, we are treating a biological glaucoma!? And we treat successfully. So why does "glaucoma epistemological" reserve the right of "incurability"? Let's try to find ways and approaches to its treatment.

\section{2. "Second-Order" Fallacy}

Let's consider one more general question. Very often we come across the criticism of some concepts - by others, who believe that their critically acclaimed concepts are entitled to such criticism. That means that representatives of these concepts believe that they themselves and shared by them views are "above" or figuratively speaking — on the "second floor" from the height of which they can easily criticize the concepts of the lower one. Apparently, they implicitly believe that their own concepts are related to "the second order" of complexity. There is a natural question: on the base of what does it arise?

To answer this question, we give two representative examples that we have discussed yet. [11, Ch. 2].

First example. The preconditions for the appearance of a "second-order fallacy" can be found, for example, in L. Wittgenstein's "Philosophical Studies", where a model of "language games" was presented [19]: "7. We can also think of the whole process of using words in (2) as one of those games by means of which children learn their native language. I will call these games 'language-games' and will sometimes speak 
of a primitive language as a language-game. And the processes of naming the stones and of repeating words after someone might also be called language-games".

His reasoning in "Philosophical Research" Wittgenstein begins with the analysis of the language: the procedures of designation and naming. Considering the use of words in natural language, he gradually leads the reader to the idea that the system of meanings of names that Frege proposed was confronted with semantic and pragmatic difficulties. Frege believed that the meaning of names are the objects they designate: "A logically complete language (Begriffsschrift) should satisfy the conditions, that every expression is grammatically well-constructed as a proper name out of the signs already introduced in fact designate an object, and that no new signified as a proper name without having a referent assured. The logic books contain warnings against logical mistakes arising from the ambiguity of expressions. I regard as no less pertinent a warning against the apparent proper names with no referents" [8. P. 222]. However, Wittgenstein specifically selects such cases - for example, the case with the magic sword of Notung from "The Song and the Nibelungs" - when a name cannot be associated with any object as its meaning, while admitting that the pointed sword does not exist as a whole, but only as a set of parts: the handle, the blade, etc. As a result, it turns out that Frege's demand is excessively strict or simply unrealizable.

But, how then to act with names with which we cannot immediately and directly compare the object? Does this mean that they are all ambiguous names or pseudo-names, as Frege suggested? [8. P. 222]. No, Wittgenstein finds a way out of this "impasse of naming" by referring to the domain of using of names: "43. For the large numbers of cases, we do not know the meaning of "meaning can be defined thus: the meaning of the word is its use in the language (italics my- $A P$ )". And if so, then the truth is just a proper use of a name in a language. In this definition of Wittgenstein, the key is the predicate "to be use in language".

And here it is impossible not to pay attention to the self-predictability of this statement. In fact, if one strictly follows this definition of Wittgenstein's "meaning", then we will have to admit that the meaning of the name "use in the language" is an "object" that depends on the use in a language, and therefore does not exist "l i $\mathrm{m}$ i t e d" of use in a language, therefore, the definition is incorrect. The fact is that putting the value of a name in dependence with the use in the language, we forget that the definition itself, given by Wittgenstein, is also "use in the language", that is, we make it "relative", referred to the language. Being related to something ceases to fulfill some universal significance. Here Wittgenstein commits his first epistemological yawn, believing that he is on the "second floor".

However, this approach is also not entirely simple. Because language is natural, it contains an unimaginable variety of uses. How in this case to avoid chaos? For the correct naming Wittgenstein introduces the notion of a language "paradigm", in which cultural or social context is easily recognized, that means certain norms for the use of linguistic expressions (Fragments 55-58).

The fear of losing a paradigm prompts us to seek reflexively some clarity and certainty in the language. We naively believe that it is internally logically ordered, as Frege thought, "105. When we believe that we must find that order, must find the ideal, 
in our actual language, we become dissatisfied with what are ordinarily called 'propositions', 'words', 'signs'. The proposition and the word that the logic deals with are supposed to be something pure and clear-cut. And we rack our brains over the nature of the real sign or the idea at the present moment?"

But is it so? Is there a genuine logical language? Wittgenstein believes that this is one of the main fallacies of the European tradition of thinking. Why? He gives an explanation: "107. The more narrowly we examine the actual language, the sharper becomes the conflict between it and our requirement. (For the crystalline purity of logic was, of course, not the result of the investigation: it was a requirement.) The conflict becomes intolerable; the requirement is now in danger of becoming empty. - We have got on to slippery ice where there is no friction and so in a certain sense. We want to walk: so, we need friction. Back to the rough ground! (italics my - A.P.)". What is this "rough ground"? What is its nature? Wittgenstein finds it in the field of human real needs: "The preconceived idea of crystalline purity can only be removed by turning out our whole examination round. One might say: the axis of reference of our examination must be rotated, but about the fixed point of our real need" (Fragment 108). Wittgenstein consciously commits a philosophical turn, abandoning the soil of "strict" logic and revealing the basis for further philosophizing in the daily use of language (Fragment 116).

Then he says: "118. Where does our investigation get its importance from, with it, it seems only to destroy everything interesting, that is, all that is great and important? (It was all the buildings, leaving behind only bits of stone and rubble.) What we are destroying is nothing but houses of cards (italics my - A.P.) and we are clear".

As "houses of cards" of Wittgenstein there is an any form of rational explanation, coupled with logic. In such destruction, the end justifies the means, because "120. When I talk about language (words, sentences, etc.) I must speak the language of every day".

Here we are faced, for the second time, with Wittgenstein's "epistemological yawn". Indeed, declaring that only "houses of cards" are being destroyed, Wittgenstein silently eludes the question of whether his own concept of "an everyday use of language" and "language games" (and the destruction of house of cards behind it) is just as accurate houses of cards? The answer arises by itself - of course, it is.

Second example. Another illustrative example is the concept of "the constructive empiricism" of Bas van Fraassen, who also believes that he has proclaimed a new program called Constructive Empiricism - $\boldsymbol{C E}[6 ; 7]$. The basic statements of the $\boldsymbol{C} \boldsymbol{E}$ on an issue under discussion were as follows:

1. Theories speak not about truth, but about facts.

2. Facts are described by empirical statements.

3. The purpose of science is to formulate theories that are empirically adequate.

4. Adoption of the theory implies only belief that the theory is empirically adequate.

5. The theory is empirically adequate if its consequences are observable.

We see that van Fraassen eliminates the truth from the explanation of scientific knowledge, replacing it with "adequacy". Strikingly, as if following by Wittgenstein, van Fraassen reduces the establishment of "adequacy" to the communicative community, with the only difference from the first, that by Wittgenstein the community communicates on "everyday language" and by van Fraassen's on "scientific language". 
In addition, van Fraassen does not justify sufficiently adequacy of his "adequacy" to modern natural science, which he talks about in his main work [6].

So, the conclusion that arises after considering the "second-order" concepts is simple: their authors think that their models (concepts) are certainly true or adequate.

In other words, my argument reduces to the fact that:

- any deflationary concept that denies or eliminates the truth, itself - for its own self-affirmation - must assume itself "true". After all, otherwise, the deflationary concept of "truth" itself falls under its own assertion "there are no true statements" or somewhat stricter and in Fregian sense — "truth" as an object does not exist. Obviously, here we deal with self-predictability. After all, if "true sentences" or "truth the object of true sentences" do not exist, then, consequently, this very sentence is not true (does not point to such object as "truth"). But, if this sentence is "false" then it is true, etc. We come to a difficulty resembling the "paradox of a liar". Elimination of truth from reasoning and valuation of sentences often leads to its confusion with lies. Remembering that "false" in Greek is called $\psi \varepsilon \dot{\varepsilon} \mu \alpha \tau \alpha$ (psemata) and the "truth" is called $\alpha \lambda \eta \dot{\eta} \theta \varepsilon 1 \alpha$ (aleteya), we call such mixed concepts "aletopsematical", and the very tendency on such mixture - "aletopsematism".

For me, another side of this problem is also interesting: what will happen if we stand up on a side of an advocate of deflationary concept that allows the redundancy (absence) of truth in our evaluation of the proposals and assume that there are not only "true proposals" but also "false proposals". Such conclusion he cannot prevent. So, what do we get in the end?

\section{3. "THE PSEMATICAL PARADOX", ARISING AT THE ELIMINATION OF FALSE}

So, the followers of the deflationary model of truth believe that, having easily coped with the task of eliminating "truth" from knowledge and describing the world, they finally solved the most difficult problem for them — need to include truth as a value of propositions in a communicative discourse or in a community of "constructive empiricists" - inherited from the antiquity to the modern empiricists and fallibilists. However, I think they are completely unaware that, having coped with one problem, they immediately face another, much more complexed and difficult.

After eliminating the "truth" from the knowledge, they will have with the need to eliminate "false". But this, in my opinion, leads to an obvious absurdity, to be more exact - to a paradox that resembles the heterological paradox [17].

Here we introduce Frege's classical assumption [9. P. 205], which he has provided in form of two theses, that:

(I). Every true sentence denotes the truth,

(II). Every false sentence denotes the false.

and, relying on it, we will outline the essence of the problem.

To demonstrate this difficulty, consider two types of sentences:

(1) "True sentence", in Frege's sense, is a sentence that itself has that sign ("to be true"), which it designates as an object. 
Otherwise, i.e. in the case of not recognizing it as true, we would have to admit that the "true sentence", which "denotes truth as an object", is itself not true, which is obviously absurd. In other words, the statement "every true sentence denotes the truth" cannot be not true.

Thus, it turns out that Frege's assertion (I) is essentially autological in the sense of L.Nelson and K.Grelling [17. P. 338-384].

Now consider the second type of sentence — "false", which we define, as logic demands, through negation of "true sentences", that is, as is customary in modern analytic philosophy, denoting the "true sentence" by the symbol $\boldsymbol{p}$, and the "false sentence" by negating the symbol denoting the true sentences of $\neg \boldsymbol{p}$ and giving a definition:

(2) $A$ "false sentence" is not a true sentence, that is, $\neg \boldsymbol{p}$.

Now we will give these definitions a more complete form:

(A) The sentence that "true sentences have the feature of "being true"" is a sentence in which some term $\boldsymbol{p}$ ("true sentence") itself has that feature of X ("to be true"), which it designates as an object. Non-recognition of this, as we noted above, leads to absurdity.

Consequently, according to the definition of false sentences (2), it turns out that the sentence "every false sentence denotes a false" should look like this:

(B) "Any non-true sentence ( $\neg \mathrm{p})$ denotes non-truth $\rceil \mathrm{X}$ ".

The question arises: can it itself be true? The answer seems to be self-evident: of course, it can, because it is a sentence of the metalanguage and there is no need to apply to it the values of the object language. But, what confuses us here? I think - the following: the truth, as it seems to me, precisely in the sense of Frege - as an ideal object - is autological, and the false is not.

In other words: everything that is inherent the truth is true. This is clearly seen with the thesis (I) of Frege.

In fact, with the proposition — "true sentences possess the sign of "being true", represented in the form of:

Question ( $\alpha$ ): "Can the proposition 'a true sentence which denotes the truth' be true?"

problems do not arise: it is obvious that the true sentence is therefore true, when has the feature that the object designated by it has — "to be true".

But in the second case, there arises a difficulty of logical property: can a "false proposition" possess the sign that it designates, that is, "not be true". Or somewhat stricter in form of:

Question (及): "Can the proposition 'a false sentence which denotes the false' be false?"

Immediately there can arise an objection to the incorrectness of such assertion, since in the Frege's statement there is a matter of metalanguage, and the metalanguage is not obliged to possess the properties of an object language, that is, of the language about which the metalanguage is proposed - such an ideal object as "truth" or "false". It seems to be all right. But if this is so, then we cannot say anything definite about the statement (I). After all, then it turns out that it also "hangs in the air", because it does not possess the property of the object pointed to - "to be true". As we noted above regarding assertion (I) - in this case it turns out to be absurd. 
Note that this question is very similar to the question in the heterological paradox: "can the notion 'heterological' be heterological?" [20].

After all, if "truth" as "an object of true sentences" does not exist, then, consequently, this very our sentence is not true (does not point to such an object as "truth"), unless we understand the truth in the object language and metalanguage in different meanings.

Further we agree to understand under the quoted statement (II) of Frege "every false sentence denotes false" - only the name of that false sentence, which denotes false. At the same time, the unquoted expression that every false sentence denotes false we will regard as an object judged by the sentence-name (quoted).

Having agreed on this, we will give our expression a stricter form in accordance with the definition of false sentence (2), which says that "False sentence" is not a true sentence, that is, " $\neg \boldsymbol{p}$ ". In the end, we get:

The sentence "every false sentence denotes false" denotes every false sentence denoting false, if and only if, "every false sentence denoting false" is not a sentence denoting the truth.

Now, instead of expression "denoting the truth", we substitute the definition of a sentence denoting the truth. As a result, we get:

The sentence "every false sentence denotes false" denotes every false sentence denoting false, if and only if, "every false sentence denoting false" is not every true sentence denoting the truth.

The result is the following:

a) if "every false sentence denoting false" itself is not every true sentence denoting the truth, then, by the definition of "every false sentence denoting false", it is not a sentence denoting false.

and vice versa,

b) If "every false sentence denoting false" itself is every true sentence denoting the truth, then, consequently, it is "every false sentence denoting false" and it is a sentence denoting false.

In any case, it turns out that the proposition "false sentences denote false", simultaneously have the sign that they designate and do not have it. As a result, we come to the paradox: "false sentences at the same time have the sign "to be false (not true)' $(\neg$ p) and do not have them $(\neg \neg$ p)", or, given that $(\neg \neg$ p $\equiv$ p) in formal expression:

$$
\neg \mathrm{p} \leftrightarrow \mathrm{p}
$$

We see that we were led to this difficulty by the answer to the question $(\beta)$.

This paradox suggests that false judgments:

a) considered not just as human propositions, namely ontologically — are phantoms (from the Greek $\varphi \alpha ́ v \tau \alpha \sigma \mu \alpha$ (phantasma) - a ghost).

b) have a heterological nature because the proposition "Every false sentence denotes false" cannot be false.

By the analogy with critics of the heterological paradox that we find in von Wright's work [20], one could say that the definition of a false sentence through the negation 
of a true sentence is incorrect, since the absence of a sign is not itself a sign, but in that case, we find ourselves in an even more difficult situation: after all, all modern logic is literally based on an understanding of "false" exactly how "denying the truth". And that objection, voiced by von Wright, which passes with respect to the heterological paradox, does not pass in the case of a paradox that I would call "psematical", from the Greek $\psi \varepsilon \dot{\mu} \mu \alpha \tau \alpha$ — "false".

There are no references to false sentences, they do not point to anything, just as Putnam's "Brains in a Vat" cannot point to anything. But, thus, the world of false sentences delimits the world of true sentences, which, in the case considered above, themselves have a sign of the object to which they point. Or very briefly: it is impossible to agree with Frege in this matter - such object as "false" simply does not exist.

The result is an amazing conclusion: a false, paradoxically — in a literal and figurative sense - saves the truth.

(C) Pavlenko A.N., 2017

\section{REFERENCES}

[1] Anisov AM. The formal epistemology. The problems of Reality and Truth. Epistemology: the perspectives of evolution. M.: Kanon+, 2012. (In Russ).

[2] Aristotle, Metaphysics // Collected works in 4 volumes, Moscow, 1976, V. 1, 550 p. (In Russ).

[3] Armour-Garb, B. 'Horwichian Minimalism and the Generalization Problem', 2010. Analysis 70 (4): $693-703$.

[4] Ayer AJ. 'The Criterion of Truth' - Analysis, v. 3, No. 3, Jan. 1936. Pp. 28 -29.

[5] Ayer A.J. Language, Truth, and Logic. 2nd ed. L., 1946. Ch. 5.

[6] Fraassen BC. van. The Scientific Image, Oxford: Clarendon Press, 1980.

[7] Fraassen BC. van. Empiricism and the Philosophy of Science', in Churchland and Hooker, 1985, pp. $245-308$.

[8] Frege G. Sense and reference. The Philosophical review. Volume 57, Issue 3 (May 1948).

[10] Horwich P. Truth. Oxford, 1998, 176 p.

[11] Pavlenko A. The Limits of Intersubjectivity (A Critical View on the Communicative Ability for the justification of Knowledge). SPb., 2012, 278 p. (In Russ).

[12] Pavlenko A. Theorem about "back of the head". Skepsis; 2004. XVII; 210-224.

[13] Pavlenko Andrey. Skepticism against skepticism. Proceedings of the XXII World Congress of Philosophy, Korea, 2008. p. 205-216.

[14] Pavlov SA. Basis Statements of the Truth Theory with the Truth Operator. Bulletin of Peoples' Friendship University of Russia, Series Philosophy. 2009 (3): 100-113. (In Russ).

[15] Putnam H. Reason, Truth and History. Cambridge University Press, 1981, 236 p.

[16] Quine WV. Philosophy of Logic. Englewood Cliffs Prentice Hall, 1970.

[17] Ramsey FP. 'Facts and Propositions' - In: The Foundations of Mathematics. L., 1931.

[18] Tarski A. The Semantic Conception of Truth and the Foundations of Semantics. Philosophy and Phenomenological Research, 1944; 4(3): 341-375.

[19] Wittgenstein L. Philosophical investigations, Translated by GEM Anscombe. Basil Blackwell, $1958,250 \mathrm{p}$.

[20] Wright von GH. Philosophical Papers of Georg Henrik von Wright. Vol. II: Philosophical Logic. Cornell University Press, Ithaka, New York, 1983. 


\title{
ГЛАУКОМА ЭПИСТЕМОЛОГИЧЕСКАЯ И ПСЕМАТИЧЕСКИЙ ПАРАДОКС (автологичность Истины и гетерологичность лжи)
}

\author{
А.Н. Павленко \\ Институт философии РАН \\ Гончарная ул., 12, стр. 1, Москва, Россия 109240
}

В работе рассмотрены основные аргументы дефляционной концепции истины: подходы А. Тарского, У.В. Куайна, Х. Патнема и некоторые другие. Приведены два репрезентативных примера элиминации истины как выделенной оценки суждений: концепция «языковых игр» Л. Витгенштейна и «конструктивный эмпиризм» Б. ван Фраассена. Выявлено, что утверждение о том, что «,,истины“, как выделенной оценки суждений, не существует» является самопредикативным и приводит к нелепости. Продемонстрировано, что элиминация (избыточность) «истины» из познания, с необходимостью, затребует и элиминацию «лжи». Показано, что при ответе на вопрос "может ли «ложное предложение», понимаемое как предложение «не истинное», то есть $\neg$ p, обладать тем признаком, которое оно обозначает как объект «ложь», то есть «быть не истинным»?", возникает парадокс,

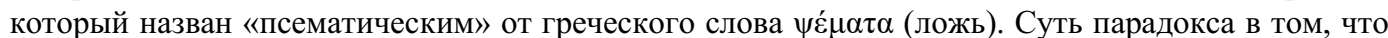
a) если «всякое ложное предложение, обозначающее ложь» само не является всяким истинным предложением, обозначающим истину, то оно, по определению «всякого ложного предложения, обозначающего ложь» - не является обозначающим ложь. И, наоборот, б) Если «всякое ложное предложение, обозначающее ложь» само является всяким истинным предложением, обозначающим истину, то, следовательно, оно является «всяким ложным предложением, обозначающим ложь», и обозначает ложь. В любом случае получается, что суждение «ложные предложения обозначают ложь» одновременно и обладает тем признаком, который оно обозначает, и не обладает им. Обнаружено, что «истина» обладает автологической природой, а «ложь» — гетерологической.

Ключевые слова: псематический парадокс, истина, ложь, логика, эпистемология, онтология, конструктивный эмпиризм, языковые игры, Г. Фреге, А. Тарский, У.В. Куайн, Х. Патнем

\section{Для цитирования:}

Павленко А.Н. Глаукома эпистемологическая и псематический парадокс (автологичность истины и гетерологичность лжи) // Вестник Российского университета дружбы народов. Серия: Философия. 2018. Т. 22. № 2. С. 158-167. doi: 10.22363/2313-2302-2018-22-2-158-167.

\section{For citation:}

Pavlenko, A.N. The epistemological glaucoma and psematical paradox (autological feature of truth and heterological feature of false). RUDN Journal of Philosophy. 2018; 22 (2):158-167. doi: 10.22363/2313-2302-2018-22-2-158-167.

\section{Сведения об авторе:}

Павленко Андрей Николаевич - доктор философских наук, профессор, ведущий научный сотрудник, руководитель группы «Онтология» сектора теории познания Института философии PAH (e-mail: anpavlenko@mail.ru). 